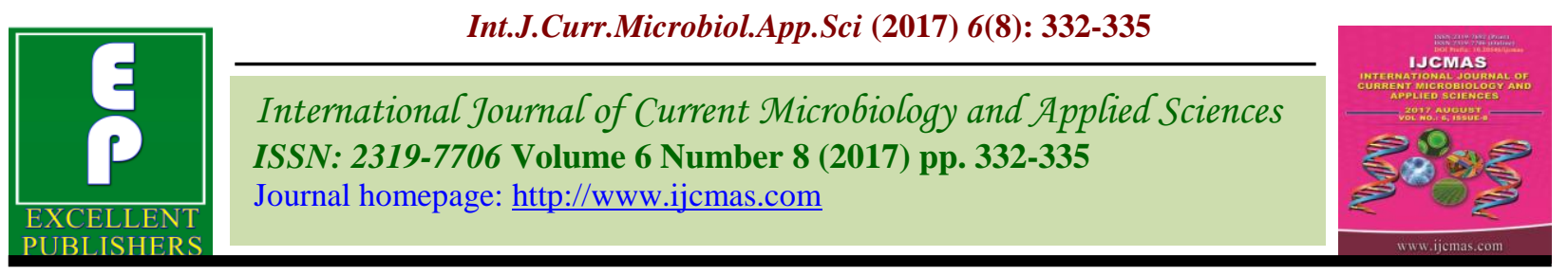

Original Research Article

https://doi.org/10.20546/ijcmas.2017.608.043

\title{
Correlation and Genetic Variation of Thirty Four Different Genotypes of Moringa (Moringa oleifera, Lam.) in Tamil Nadu Condition, India
}

\author{
P. Selvakumari ${ }^{1 *}$ and V. Ponnuswami ${ }^{2}$ \\ ${ }^{1}$ Horticultural Officer, Perambalur, Tamil Nadu, India \\ ${ }^{2} \mathrm{HC} \&$ RI, Periyakulam- 625 604, Tamil Nadu, India \\ *Corresponding author
}

\section{A B S T R A C T}

Keywords

Moringa, Correlation, Heritability, Genetic advance.

Article Info

Accepted:

04 June 2017

Available Online:

10 August 2017
Field study has been conducted at Horticultural College and Research Institute, Periyakulam for evaluating the genetic variability and association among characters during the year 2011-12. The phenotypic coefficient of variation $(\mathrm{PCV})$ was higher than genotypic coefficient of variation $(\mathrm{GCV})$ for all the eight characters studied. The higher PCV and GCV estimates were found for number of flowers per branch let followed by fruit weight. High heritability with high genetic advance was observed for flowers per branch let, length of the fruit and fruit weight. The correlation studies revealed that plant height exhibited positive correlation with trunk girth, number of flowers/branch let, length of fruit, fruit girth, fruit weight, number of seeds/fruit. There exists a positive relationship of length of fruit with fruit girth, fruit weight, number of seeds/fruit and number of pods/tree.

\section{Introduction}

Moringa oleifera Lam. (synonym: $M$. ptreygosperma Gaertn.), an economically important multipurpose tree indigenous to northwest India, is the most widely cultivated, applied, and well-known one of all 13 species in the monogeneric family Moringaceae (Olson, 2002). Popularly known as "Drumstick"' tree, horseradish tree, or Ben tree, $M$. oleifera is a deciduous to evergreen shrub or small tree with a height of 5 to $10 \mathrm{~m}$ (Morton, 1991). Its seedlings are fast growing with early sexual maturity and a height up to $4.5 \mathrm{~m}$ in 9 months and flowering in half a year (Von Maydell, 1986). M. oleifera used to distribute wildly in the forests of Western
Himalaya, and then throughout India by cultivation (Selvam, 2005). Featured by richness in proteins, minerals, and vitamins, the leaves of $M$. oleifera are used as a highly nutrient vegetable and as cattle fodder (Mughal et al., 1999).

Despite limited knowledge of the levels of genetic diversity and relatedness of introduced populations, their utilization as a source of seed for planting is widespread. Knowledge of population genetic diversity is one of the basics for development of plant species conservation strategies. In the case of wild species that represent genetic resources 
for cultivated plants, an understanding of their genetic diversity is essential as they are the source of genetic material that are used to improve elite varieties.

The study of interrelationship of various characters in the form of correlation is an important aspect in crop breeding. Information of correlation studies helps the plant breeder to ascertain the real components of yield and provide an effective basis of selection.

The characters contributing significantly to desirable traits can be significantly identified and can be used as alternate selection criteria in crop improvement programme. Very little work on this aspect has been reported in moringa, hence the present study was undertaken to find out the association among important quantitative characters in moringa.

\section{Materials and Methods}

The materials under study were constituted of 34 local genotypes. The observations on various characters were recorded on selected three plants of each moringa genotypes.

The morphological observations were recorded on various aspects viz., plant characters, plant growth, flowering intensity, plant girth, tree height, number of flowers/branchlet, length of fruit, number of seeds per fruit, fruit weight, and number of pods/tree.

Data were analysed and presented in tabular form. Data were put to statistical analysis as per Panse and Sukhatme (1967). Genetic parameters like genotypic coefficient of variation (GCV) and phenotypic coefficient of variation (PCV) were estimated according to Burton and Vane (1953) and heritability as suggested by Weber and Moorthy (1952). Correlation analysis was carried out as per the formulae suggested by Fisher (1954). The significance of phenotypic and genotypic correlation coefficients was tested against ' $r$ ' value given in Fisher and Yate's table (1963) at (n-2) degrees of freedom.

\section{Results and Discussion}

The phenotypic coefficient of variation (PCV) and genotypic coefficient of variation (GCV) (Table 1) was the highest for number of flowers/branchlet followed by fruit weight, trunk girth, length of fruit suggesting that these characters are under genetic control. Hence, these characters can be relied upon selection for further improvement.

The phenotypic coefficient of variation (PCV) was higher than genotypic coefficient of variation $(\mathrm{GCV})$ for all the characters under study, indicating the role of environment in expression of genotype. Similar results were also reported by Kumar et al., 2013 in sponge gourd. Minimum values of phenotypic coefficient of variation (PCV) and genotypic coefficient of variation (GCV) were recorded for characters like plant height, number of seeds/fruit and number of pods/tree. This type of findings indicated that very minimum variation existed among the genotypes with respect to these characters.

High heritability coupled with high genetic advance was observed for trunk girth, number of flowers/branchlet, length of fruit and fruit weight (Table 1). This indicates the lesser influence of environment in expression of these characters and prevalence of additive gene action in their inheritance hence, suitable for selection. High heritability with moderate genetic advance was recorded for fruit girth and number of seeds/fruit suggesting the presence of both additive and non-additive gene actions, and simple selection offers best possibility of improvement of this trait. The estimate of heritability was high with low genetic advance as percentage of mean for 
plant height and number of pods/tree which indicated that high heritability were due to non-additive gene effects and influence of environment.

The genotypic and phenotypic correlation coefficients were computed in all possible combinations for eight characters and are presented in tables 2 and 3. Correlation coefficient analysis measures the mutual relationship between various plant characters and determines the component characters on which selection is based for genetic improvement for a particular character (Robinson et al., 1949). A positive correlation between desirable characters is favorable to the plant breeder because it helps in simultaneous improvement of both the characters. In the present study, genotypic correlation coefficients were found to be higher than phenotypic correlation coefficients for most of the characters, indicating a strong inherent association between various characters and were masked by environmental component with regard to phenotypic expression. Similar findings have also been reported by Singh et al., (2002) in ridge gourd and Kutty and Dharmatti (2004) in bitter gourd. Plant height exhibited a positive and significant association with trunk girth, number of flowers / branchlet, length of fruit, fruit girth, fruit weight at both genotypic and phenotypic levels. But it had a highly significant and negative correlation with number of seeds/fruit.

Table.1 Estimates of variability and genetic parameters for vegetative and yield characters

\begin{tabular}{|c|l|c|c|c|c|c|c|}
\hline S.No & \multicolumn{1}{|c|}{ Characters } & Mean & Range & GCV & PCV & Heritability (\%) & GA (\%) of Mean \\
\hline 1. & Plant Height & 5.17 & $3.2-7.8$ & 19.69 & 19.70 & 88.83 & 32.47 \\
\hline 2. & Trunk girth & 140.69 & $70.75-250.74$ & 28.67 & 28.70 & 99.88 \\
\hline 3. & No. of flowers / branchlet & 22.38 & $10.49-48.29$ & 37.04 & 37.07 & 96.24 \\
\hline 4. & Length of fruit & 58.86 & $22.70-92.66$ & 23.29 & 23.31 & 99.84 & \\
\hline 5. & Fruit girth & 8.48 & $6.50-12.67$ & 15.78 & 15.79 & 95.00 & 76.23 \\
\hline 6. & Fruit weight & 119.94 & $30.57-212.67$ & 32.79 & 32.82 & 99.02 & 40.93 \\
\hline 7. & No. of seeds/fruit & 20.75 & $10.35-25.37$ & 17.88 & 17.90 & 96.79 & \\
\hline 8. & No. of pods /tree & 98.76 & $54.20-135.82$ & 20.06 & 20.08 & 97.50 & 95.53 \\
\hline
\end{tabular}

Table.2 Phenotypic correlation coefficient among different characters in Moringa

\begin{tabular}{|l|c|c|c|c|c|c|c|c|}
\hline \multicolumn{1}{|c|}{ S. No } & $\begin{array}{c}\text { Plant } \\
\text { Height }\end{array}$ & $\begin{array}{c}\text { Trunk } \\
\text { girth }\end{array}$ & $\begin{array}{c}\text { No. of flowers / } \\
\text { branchlet }\end{array}$ & $\begin{array}{c}\text { Length of } \\
\text { fruit }\end{array}$ & $\begin{array}{c}\text { Fruit } \\
\text { girth }\end{array}$ & $\begin{array}{c}\text { Fruit } \\
\text { weight }\end{array}$ & $\begin{array}{c}\text { No. of } \\
\text { seeds/fruit }\end{array}$ & $\begin{array}{c}\text { No. of pods } \\
\text { /tree }\end{array}$ \\
\hline Plant Height & 1.000 & $0.404^{*}$ & 0.019 & 0.228 & 0.036 & 0.164 & 0.023 & -0.020 \\
\hline Trunk girth & & 1.000 & $0.353^{*}$ & 0.082 & -0.012 & -0.095 & -0.078 & -0.245 \\
\hline No. of flowers / branchlet & & 1.000 & -0.069 & 0.114 & -0.230 & 0.033 & -0.207 \\
\hline Length of fruit & & & & 1.000 & 0.032 & $0.479^{* *}$ & $0.685^{* *}$ & 0.054 \\
\hline Fruit girth & & & & 1.000 & -0.162 & 0.109 & 0.021 \\
\hline Fruit weight & & & & & 1.000 & 0.306 & 0.012 \\
\hline No. of seeds/fruit & & & & & & & & \\
\hline No. of pods /tree & & & & & & & & \\
\hline
\end{tabular}

* Significant at 5\% level; ** Significant at $1 \%$ level

Table.3 Genotypic correlation coefficient among different characters in Moringa

\begin{tabular}{|c|c|c|c|c|c|c|c|c|}
\hline S. No & $\begin{array}{c}\text { Plant } \\
\text { Height }\end{array}$ & $\begin{array}{c}\text { Trunk } \\
\text { girth }\end{array}$ & $\begin{array}{c}\text { No. of flowers / } \\
\text { branchlet }\end{array}$ & $\begin{array}{c}\begin{array}{c}\text { Length of } \\
\text { fruit }\end{array} \\
\end{array}$ & $\begin{array}{l}\text { Fruit } \\
\text { girth }\end{array}$ & $\begin{array}{c}\text { Fruit } \\
\text { weight }\end{array}$ & $\begin{array}{c}\text { No. of } \\
\text { seeds/fruit }\end{array}$ & $\begin{array}{c}\text { No. of pods } \\
\text { /tree }\end{array}$ \\
\hline Plant Height & 1.000 & $0.521 * *$ & 0.153 & $0.357^{*}$ & 0.103 & 0.251 & 0.189 & -0.217 \\
\hline Trunk girth & & 1.000 & $0.427 * *$ & 0.192 & -1.292 & -0.099 & -0.145 & -0.426 \\
\hline Length of fruit & & & & 1.000 & 0.251 & $0.532 * *$ & $0.813 * *$ & 0.148 \\
\hline Fruit girth & & & & & 1.000 & -0.252 & 0.237 & 0.179 \\
\hline Fruit weight & & & & & & 1.000 & $0.479 * *$ & 0.217 \\
\hline No. of pods /tree & & & & & & & & 1.000 \\
\hline
\end{tabular}

* Significant at 5\% level; ** Significant at $1 \%$ level 
Trunk girth exhibited a positive and significant association with number of flowers/ branchlet and length of the fruit in both phenotypic and genotypic levels. But this character had negative correlation with fruit girth, fruit weight, number of seeds/fruit and number of pods/tree. In both genotypic and phenotypic levels, there exists a positive relationship of number of flowers / branchlet with fruit girth and number of seeds per fruit. But it had negative association with length of the fruit, fruit weight and number of pods/tree.

There exists a positive and highly significant relationship of length of fruit with fruit girth, fruit weight, number of seeds/fruit and number of pods/tree. Similar results are reported by Das et al., (2012) in okra. Fruit girth showed positive and highly significant association with number of seeds/fruit and number of pods/tree. Its association with fruit weight was found to be negative. Fruit weight exhibited positive and significant association with number of seeds/fruit and number of pods /tree. There exists a positive and highly significant relationship of number of seeds/fruit with number of pods/tree. This is in consonance with the findings of Das et al., (2012) in okra.

On the basis of this study, it can be concluded that selection would be rewarding for number of flowers per branchlet, trunk girth, length of the fruit and fruit weight in bringing out the improvement in the moringa because they appeared with high value of GCV, PCV, heritability and genetic gain. Further, correlation study also suggested that for improvement in yield, selection for such a plant having more number of fruits, greater weight of fruit, more length of fruit and more diameter of fruit would be beneficial.

\section{References}

Burton, G. W., and Vane, D. 1953. Estimating heritability in late fescue from replicated clonal material. Agronomy Journal. 45, 478479.

Das, et al., 2012. Genetic parameters and path analysis of yield and its components in okra at different sowing dates in the Gangetic plains of eastern India. African Journal of Biotechnology. 11(5), 16132-16141.

Fisher, R. A. 1954. Statistical Methods for Research Workers. Din Oliver and Boyd ltd. London, United Kingdom.

Kumar, et al., 2013. Genetic variability, correlation and path analysis in sponge gourd (Luffa cylindrica Roem.). African Journal of Biotechnology. 12(6), 539-543.

Kutty. M. S and Dharmatti, P. R. 2004. Genetic variability studies in bitter gourd (Momordica charantia L.). Karnataka Journal of Horticulture. 1(1), 11-15.

Morton, J. F. 1991. The horseradish tree, Moringa pterygosperma. (Moringaceae) - a boon to arid lands. Economic Botany. 45, 318 - 333.

Mughal, et al., 1999. Drumstick Moringa pterygsperma Gaertn: A unique source of food and medicine. Journal of Economic and Taxonomic Botany. 23, 47-61.

Olson, M. E. 2002. Combining data from DNA sequences and morphology for a phylogeny of Moringaceae (Brassicales). Systematic Botany. 27, 55-73.

Robinson, et al., 1949. Estimates of heritability and degree of dominance in corn. Agronomy Journal. 41, 353- 359.

Selvam, A. B. D. 2005. Distribution, phenology and utilization of Moringa oleifera Lam.: An indigenous medicinal plant of India. Journal of Economic and Taxonomic Botany. 29, 102-108.

Singh, et al., 2002. Studies on genetic variability and heritability in ridge gourd (Luffa acutangula). Agriculture Science Digest. 22(4), 279-280.

Von Maydell, H. J. 1986. Trees and shrubs of Sahel: Their characterization and uses. Deutsche Ge-sellschaft fur Technische Zusammenarbeit, Eschborn, Germany. Pp. 334-337.

Weber, C. R. and Moorthy, B. R. 1952. Heritable and non-heritable relationship and variability of soil content and agronomic characters in $\mathrm{F}_{2}$ generation of soybean crosses. Agronomy Journal. 44, 202-209. 


\section{How to cite this article:}

Selvakumari, P. and Ponnuswami, V. 2017. Correlation and Genetic Variation of Thirty Four Different Genotypes of Moringa (Moringa oleifera, Lam.) in Tamil Nadu Condition. Int.J.Curr.Microbiol.App.Sci. 6(8): 332-335. doi: https://doi.org/10.20546/ijcmas.2017.608.043 